\title{
Are the Times Changing Enough? Print media trends across four decades
}

\begin{abstract}
Media analysis is an established area of sport sociology which has been documented by researchers systematically since the 1980s. Some trends have explored the differences between male and female athletes in the print media with significant evidence demonstrating that female athletes do not gain proportional representation and that many strategies employed by journalists traditionally seek to trivialise, sexualise and emphasise the female identity as 'other' rather than as athlete. This longitudinal study uniquely documents an analysis of a two week period in the British print media across four decades 1984-2014. This study, grounded in liberal feminism, presents both quantitative and qualitative data and the main quantitative results demonstrate that coverage for female athletes has decreased from $13 \%$ to $6.2 \%$. Qualitative themes presented include: relationships, appearance, performance and nationality, the latter emerging as a new theme from the 2014 data set. The results demonstrate that there is little change in amount of representation afforded to female athletes but that there are reporting changes with a greater emphasis on performance and less reliance on appearance. The paper concludes with the position that although sports reporting, in general is on the increase, women athletes are being given less but potentially better coverage.
\end{abstract}

\section{Key words}

Print media, women, longitudinal, sport, performance 


\section{Introduction}

Media analysis is an established area of sport sociology which has been documented by researchers systematically since the 1980s. Despite the extent and breadth of the area there have been some methodological trends which include a focus on print media, the analysis of both quantitative and qualitative content and the analysis of the portrayal of female athletes. This study presents a unique analysis of the past four decades of British print media covering the same two week summer period in six national newspapers in order to assess whether societal and cultural changes have been reflected in the predominantly patriarchal domain of sport (Matheson et al., 2005; Matheson et al., 2006a, 2006b). Outcomes have been mixed, but overall it is clear that the continued under representation of not only female athletes but also what were once considered to be the major British summer sports (athletics, cricket, golf, tennis) have been replaced by a dominance of soccer reporting (in this article we use the internationally recognized term 'soccer' to refer to Association Football). This article will provide an overview of the trends documented during the last four decades and offer some insight into the growth of the 'gossip sheets' for men (Wenner, 1989).

\section{Changing Times}

Previously, research about female athletes in the media has focused on how their representation has been linked to appropriate female roles rather than that of being athletes. Vincent et al. (2002) highlighted how type of press (popular v serious) affected the way female athletes were portrayed with the popular press more likely to denigrate and trivialize female athletes. Further research by Vincent (2004) showed that the sports pages are the most widely read section of any newspaper and, therefore, the best way to sell a newspaper is to provide extensive coverage of commercial sports to the biggest commodity - the male reader. More recently, Godoy-Pressland (2013) supported the notion that sports 
journalists continue to trivialize female athletes by directing focus away from their athleticism, providing a sense that they do not fit with gendered notions of femininity. The same research also suggested that women can only succeed if they achieve a male standard in sport (Godoy-Pressland, 2013).

Bernstein (2002) reported the print media were more likely to focus on performance for female athletes who participated in female appropriate sports. However, male performance is often still linked with power metaphors (such as war) while the coverage of female athletes is often framed within stereotypes that emphasise their appearance and attractiveness rather than athletic skill. Crossman et al., (2007) concur it is only when females participate in female appropriate sports that they are afforded the type of coverage consonant with their performance. Jones et al., (1999) went so far as to state female gymnasts were more likely to have performance analysed and commented on whereas females participating in non-gender appropriate sports were not afforded the same narrative in the print media. Terminology, therefore, remains linked to societal portrayal of acceptable male and female sports and performance.

Boyle and Haynes (2000) noted that the intrusion of soccer into June and July during European and World Cup years, and the start of the English Premier League in August have resulted in greater coverage of soccer to the detriment of athletics, cricket, golf and tennis. This characteristic was noticeable in our data set despite the Wimbledon tournament being included in our data collection period. Vincent (2004) reflects that when a grand slam event takes place sports journalists have an opportunity (sic obligation?) to provide equitable coverage of male and female players and to balance social responsibility with economic rationales. It could be argued that this should override the desire to sell to the biggest commodity, the male reader (Boyle and Haynes, 2000).

While it can be shown that there have been improvements in coverage for female athletes over the past four decades (Bernstein, 2002; Crossman et al., 2007; Matheson et al., 2005; Vincent, 2004) not all of 
these improvements have been positive. Godoy-Pressland (2013) and Vincent (2004) point out it is the use of different language and asymmetrical gender marking which prevent equity; athletic roles rather than gender roles need to be the dominant discourse. Quantitative research has provided evidence that coverage for female athletes during major events increases but proportionally there has been a fall (George et al., 2001; Matheson et al., 2005; Sherry et al., 2015). Biscomb and Griggs (2013) show there is now greater awareness of performance when reporting female athletes, but there are still contradictory messages. This is supported by, for example, Eagleman (2013), Godoy-Pressland (2013) and Pedersen (2002), who subscribe to the concept that gendered language in the media continues to promote male supremacy and female subordination. Vincent et al., (2002) concluded the British popular tabloid press was more likely to denigrate and trivialize female athletes than the serious broadsheets were. Thus, social and cultural values are perpetuated.

Thematically, Kane and Greendorfer (1994) stated power, strength and athleticism might be used as descriptors but alongside these are implicit references to dependency, being vulnerable and anxious. Such ambiguity allows for an acknowledgement of social changes without newspapers having to overtly accept them. Crossman et al., (2007) expand this notion by pointing out the under representation of female athletes in sports pages can convey a message that women are not important. In fact, journalists seem to convey a double standard. Female gymnasts, apparently, need to show how easy routines are by smiling throughout, thus infantilizing their performances while male gymnasts are disempowered by participating in a sport deemed more appropriate for females (Eagleman, 2013). Godoy-Pressland (2013) intimates that representing some female athletes as 'tomboys' decreases the threat to male dominance in sport and male journalists are more likely to reinforce such gender stereotypes. Pedersen et al. (2003) concur with this view stating sport emphasizes masculinity, thus affirming male power and control and, by accepting this status quo, cultural norms prevail. Newsprint is part of that normative power because of the overwhelming dominance of coverage of male sports and athletes. 
Feminists view sport and the media as symbiotic institutions that frame sports coverage within a gendered hierarchy (Vincent, 2004). This is illustrated by the increased number of images of more powerful, strong and independent female athletes between 1994 and 2004, while there has also been an active promotion and marketing of female athletes with a heterosexual feminine appearance (Vincent, 2004). This dichotomy supports Kane and Greendorfer's (1994) notion of the media apparently making social and cultural changes but not necessarily accepting them. The marginalization of female athletes is considered normative as it is systemic within the structure of both sport and the media (Whisenant and Pedersen, 2004). Sherry et al. (2015) found that women's sport coverage is not reflective of the realities of their participation, nor audience interest. They also point out, in their review of research into images of female athletes, that women who participate in team sports (e.g. hockey and soccer) are less likely to receive year round coverage than those who participate in more gender appropriate team or individual sports (Sherry et al., 2015).

Previous research over the past four decades has continued to illustrate the notion of unfair coverage with quantitative disparity (i.e. invisibility of women), emphasis on femininity, trivialization of women's achievements, sexist language, negative reporting and focusing on physical characteristics of female athletes. These asymmetrical gender markings of sport maintain the natural dominance of males in the sporting arena. George et al. (2001) noted that the media is not necessarily the cause of such marginalization, but they certainly play a vital role in its continuation. While Crossman et al., (2007) can certainly believe that 'The times they are a-changin', Bernstein (2002) needs to hold off on her 'Victory Lap' as we are certainly not there yet! Previous research in this area, however, has largely been cross sectional with few examples presenting a longitudinal approach (see Cooky et al., 2015; GodoyPressland, 2013 and Wackwitz, 1996).

Feminist theory and perspectives are complex and until recently have been fragmented and difficult to define (Caine, 1997). Second wave feminism, emerging from the 1960s social revolution aimed to bring 
changes at both social and personal level. This research is grounded in a liberal feminist framework in that the research questions stem from a desire to illustrate the inequalities with the hope of potentially bringing about change. Ritchie et al. (2016) argue that the media, magazines particularly, can present a popular understanding of feminism. It is our belief that many women readers of newspapers may be frustrated by the lack of coverage of female athletes but not necessarily define themselves as feminists. This notion was developed further by Sheridan et al. (2006) from their analysis of Australian newspapers who note "it is impossible to draw a firm line between feminism "in actuality" and feminism in the media sphere" (cited in Le Masurier 2016: 203). Hence the motivations behind this work originate from an interest in highlighting a social practice which continues to disadvantage women. Although our work originated at the time of third wave feminism we are influenced by and reflect more the traditions of liberal feminism from the second wave perspective. Much of the literature in this field is from an international field with domination by North American authors and an acknowledgement that there are few British studies (Redman et al., 2010). The present study now adds quantitative and qualitative analyses of 2014 British sports pages, to those of 1984, 1994 and 2004, tracking changes in amount of coverage for women. Relative and proportional changes in coverage will be related to social and cultural changes that have occurred in the past four decades. In addition, there will be some quantitative analysis of the impact the infiltration of soccer into the summer has had in marginalizing team and individual sports (athletics, cricket, golf, tennis) for both women and men. This study aims to answer the question “what changes have occurred in the reporting of female athletes from 1984-2014?"

\section{Methods}

For the two week period of 1 - 14 July in 1984, 1994, 2004 and 2014 six British national daily and Sunday newspapers representing the serious broadsheet (The Guardian, Daily Telegraph), tabloid (Daily Mail, 
Daily Mirror) and midrange (Daily Express) were selected for analysis. The Independent [1994, 2004 and 2014 only] was added as an example of a new newspaper. These dates were selected as they offered opportunities for female athletes to be highly visible due to tennis (Wimbledon), golf (qualifying competitions for Weetabix/Ricoh British Open), athletics (qualifying competitions for World Cup/World Championships, and, in later data collections, Diamond League Meetings) and cricket Tests, One Day Internationals, Twenty/20 competitions. In addition, Tour de France, motorsport and rugby league were in season, with soccer and Rugby Union in preseason modes. In 1984 and 2004 the Olympic Games started less than four weeks after completion of data collection. In 1994 and 2014 the Commonwealth Games began within a month of data collection completion, thus providing enhanced opportunities for female athletes to be reported. Hard copies of all newspapers were utilized for data collection purposes. Table 1 outlines the demographic information relating to the newspapers chosen. The Daily Mail has the largest circulation for any paper and The Independent has the smallest circulation, which subsequently resulted in the cancellation of the print version.

\section{INSERT TABLE 1 HERE}

Quantitatively articles and photographs were counted and attributed to male sport, female sport or both male and female sport. Type of sport was also categorized according to the activity. Only photographs and articles appearing on the sports pages were included in data sets one and two and column inches were calculated for all such articles and photographs. This proved to be a limiting factor for data collections 2004 and 2014 when desktop publishing was utilized for newspaper publications; however, in 1984 and 1994 newspapers had used traditional typesetting with designated headlines, column inches and limited photographs. The decision was taken in 2004 to retain data collection from sports pages only and to change methodology to count in the designated categories as above, as it was no longer deemed accurate to measure column inches. 
Other descriptive data collected on individual papers included the following:

- name of newspaper

- date of publication

- day of the week

- number of sports pages (excluding those solely reporting horse racing)

- number of total newspaper pages (excluding magazine inserts and guides)

- tabloid or broadsheet

Each article or photograph was entered as a case in SPSS v20. A total of 17,257 cases were entered. Seven individual papers were entered a second time (220 cases) to establish Cronbach's Alpha coefficient of reliability. Cronbach's Alpha coefficient of reliability ranges in value from 0 to 1 and may be used to describe the reliability of factors extracted from dichotomous data. The higher the score, the more reliable the data can be presumed to be. Nunnaly (1978) has indicated 0.7 to be an acceptable reliability coefficient but lower thresholds are sometimes used in the literature.

In our case, we calculated the coefficient based on the recording of cases by paper in the initial data entry and in the group of re-entered cases. We found a coefficient of 0.996 , indicating a very close correspondence between the two data sets.

Chi square significance tests were run on the following variables:

- publication year vs. number of sports pages

- publication year vs. number of newspaper pages

- $\quad$ publication year vs type of newspaper

- publication year vs. gender of content

- publication year vs. number of photographs 
- $\quad$ publication year vs. each defined sport

Chi square was used to identify both absolute changes (e.g. changes in numbers) and relative changes (e.g. changes in percentages) across the decades.

For qualitative data hard copies of the newspaper were used to identify the titles of the articles. Proquest Newspapers (UK Newsstand) was used to search for an online version of the article which was then retrieved and uploaded into Nvivo 10. Uploaded articles were coded according to base data: type of newspaper, title of newspaper, male or female athletes and sporting activity. Deductive coding was undertaken using themes emerged from previous data collection exercises $(1984,1994,2004)$ and any emergent themes were identified by systematically inductively coding each individual article. Coding from the previous data sets was undertaken in earlier iterations of the research project.

\section{Quantitative Results}

Overall there was a significant difference (chi square $=51.272, p .<.05)$ between type of newspapers with tabloids (Express, Mail, Mirror) including more sports pages (percent total $=53.7 \%$ ) than broadsheets (Guardian, Independent, Telegraph) (percent total $=46.3 \%)$. This was the case for all data collections except 1994 which was an Olympic year. In this instance broadsheets included marginally more percent total sports page (9.6\%) than tabloids (9.1\%). Average number of newspaper pages has risen from 35.31 in 1984 to 62.31 in 2014, with sports pages rising from 5.38 to 19.30 over the same period. Both changes are highly significant $(p<.05)$ in each case measured by ANOVA. The growth in sports coverage represents an increase in the percentage of sport to other pages from $15 \%$ in 1984 to $31 \%$ in 2014 .

INSERT TABLE 2 HERE 
Over the four decade period, coverage of women's sport has declined in proportion to men although in absolute terms, there has been a growth from 263 in 1984 to 385 in 2014 in the number of articles including women's sports coverage. The percentage of sports coverage of women has declined from $13.0 \%$ in 1984 to $6.2 \%$ in 2014 . The decline is significant (Chi squared=156.091 $p<.05$ ). Male coverage during the same period of time increased from $80.7 \%$ (1984) to $89.9 \%$ (2014). The category 'Both' (predominately male articles which included references to female athletes) increased by count (127 in $1984 ; 237$ in 2014), but decreased by percentage $(6.3 \%-3.8 \%)$.

\section{INSERT FIGURE 1 HERE}

There has been a highly significant change in the format of sports coverage over the period. In absolute terms, both text articles and photographic coverage across both types of newspaper have increased, however the percentage of coverage in photographic form has risen from $6.0 \%$ in 1984 to $46.8 \%$ in 2014. The change is significant (Chi squared $=1166.790, p<.05)$.

\section{INSERT FIGURE 2 HERE}

Focusing on gender, percentage of total photographic coverage of men (from $2.5 \%$ in 1984 to $22.7 \%$ in 2014) has increased by more than that of women (7.8\% - 1984 to $17.5 \%$ - 2014). This tessellates with the corresponding decrease in text coverage for females $(11.9 \%$ of total in $1984-11.3 \%$ of total in 2014), with an increase from $8.3 \%$ of total coverage in 1984 to $14.0 \%$ in 2014 for males. This might be seen as an indication of the growth of more considered coverage of women's sport but is more likely to demonstrate different consumer behaviour towards instant visual display in contrast to deciphering the written word.

The major sports covered in the newspapers have remained the same over the period; however, the share of coverage has changed dramatically. In absolute terms, coverage of most of these sports has increased (except for athletics). However, the proportion of coverage devoted to each sport is quite 
different in 2014. There are small increases in the proportions for cricket and cycling, but the real increase is in soccer, from $2.3 \%$ in 1984 to $51.3 \%$ in 2014 . It is worth noting that the data are for July, when the UK male soccer season has not yet started. Athletics shows a considerable decrease from 2004 (48.1\% to $14.4 \%)$, but 2004 was an Olympic year. The changes in coverage by gender for the selected summer sports is very highly significant (Chi squared=1836.803; $p<.05$ ).

\section{INSERT FIGURES 3(a-d) HERE}

The sports timeline provided below (Figure 4) illustrates the major sporting events which were taking place during the decades of data collection and offers insight into which of the selected sports were close to actual time of collection.

\section{INSERT FIGURE 4 HERE}

\section{Qualitative Results}

Qualitative data for 2014 demonstrates that there are some ongoing trends with general reporting styles. The constant comparison method (Groves and Griggs, 2016) whereby athletes are compared as individuals or groups to others to demonstrate a hierarchy remains a stable feature of reporting but some of the specific traditional reporting strategies employed by the print media to 'other' the female athlete have changed across the decades. These gender specific strategies of non-parallel language include use of titles, prefix of 'Women's' and the use of relationships. The strategy of using a female athlete's title and surname, whereas traditionally male athletes are reported using surname only, has largely been dropped by 2014. In contrast the strategy of reporting of women's as a prefix to sport, whereas men's sports do not have the prefix, remains unchanged. A notable emergence in general reporting style is the use of direct quotations from athletes, coaches or officials to extend the content of the report and ultimately serves as a cheap reporting technique. The majority of reporting for female athletes appears in tennis, which is not surprising because of the scheduling of the collection period 
within the Wimbledon tournament and reporting of tennis for both male and female athletes is extensive during this time. In contrast minority sports are often combined into one report for both male and female athletes. This pattern regularly occurs in sports such as athletics, hockey and rowing and is more likely to be a feature of minority sport reporting rather than gendered reporting. It should be noted, however, that when this approach is utilized the usual pattern is for men to be reported first and for women to be reported second. Consequently these qualitative data results focus on athletics, golf and tennis which are the main sports with the majority of female reporting occurring in the 2014 data set. Following the reporting of previous data sets (e.g. Biscomb et al., 1998) the qualitative data in this study focusses on relationships, appearance, performance and introduces nationality as a new trend within the data. The 2014 data are presented within text and then data from the previous decades are presented later to enable contrast and comparison. In the following section the qualitative themes are presented along with a short discussion specific to that theme. We then conclude the paper with an overall discussion and comments for future directions.

\section{Performance}

As noted earlier between the previous decades 1984-2004 there was a general shift away from appearance towards the reporting of skill and performance and this trend continues into 2014 . The reporting of both successful and unsuccessful performance is evident from the data particularly in tennis; the story can then be framed as either the unsuccessful performance of a particular player or the successful performance of another player for example:

Of course, gripes over the time between points should not disguise the fact that Wozniacki, formerly the world No 1, was comprehensively outplayed by her unseeded Czech opponent. Or that she failed, once again, to raise her game in the later rounds of a Grand Slam (Daily Mail $1^{\text {st }}$ July 2014).

Agnieszka Radwanska's charge through the draw came to a shocking end last night, with the fourth seed crushed by Ekaterina Makarova in less than an hour (Daily Mail 1st July 2014). 
As two examples of the report being about the defeat of a player which can be contrasted with the following reports about the success of a player:

Petra Kvitova scored one of the quickest victories in the final of the women's singles (Sunday Telegraph $6^{\text {th }}$ July 2014)

Eugenie Bouchard defeated Romania's Simona Halep 7-6, 6-2 to become Canada's first finalist at Wimbledon (Guardian $4^{\text {th }}$ July 2014).

The emphasis on which player's narrative to tell is usually based on either the highest ranking athlete or the most popular, such as the home athlete, but also serves to privilege the journalist's voice in how the match report is framed. Reporting of performance is usually more technical in athletics and golf in contrast to other sports, as these sports focus on the details of the shots and results rather than descriptive language to describe the performance:

Jodie Williams, 20, posted the quickest time by a British woman for 10 years as she ran a personal best of $22.60 \mathrm{sec}$ to finish fourth in the $200 \mathrm{~m}$ (Mail on Sunday $13^{\text {th }}$ July 2014).

The 18-year-old from Kettering lies just three shots behind the leader, South Korean Inbee Park, after she shot the lowest round of the day (Daily Express $13^{\text {th }}$ July 2014)

Uehara leads United States' Mo Martin by one shot, while world No 1 and defending champion Stacy Lewis scored one under par to trail by three. Michelle Wie endured a difficult day, scoring 75 to finish three over par (Daily Mail $11^{\text {th }}$ July 2014

This can be contrasted to: "hitting winner after winner past the bemused Pole" (Daily Express $1^{\text {st }}$ July 2014), "was comprehensively outplayed by her unseeded Czech opponent" (Daily Mail $1^{\text {st }}$ July 2014) and "performance of sheer brilliance" (Guardian $7^{\text {th }}$ July 2014). Table 7 illustrates examples of performance reporting from previous decades:

INSERT TABLE 3 HERE 
The terminology and imagery used in the descriptive reporting of performance has developed over the decades. It has become more brutal and dramatic: "executioner" stood out in 1984 because it was uncommon but by 2004 , as well as the war/battle imagery, we also saw words such as "murder", "pulverised" and "defeat". War and battle metaphors appear in the later decades for tennis including

Changing of the guard in women's tennis" (Daily Telegraph $1^{\text {st }}$ July 2004)

The Russian revolution is threatening to sweep her aside" (Daily Mirror $3^{\text {rd }}$ July 2004) ... shown all the signs of crashing through the fourth-round wall (Daily Express 1st July 2014)

Angelique Kerber battled through to take the match (Daily Express $2^{\text {nd }}$ July 2014)

which challenges Berstein's (2002) view that this metaphoric style is used only for male athletes. In contrast the imagery used for athletics reporting is more benign.

\section{INSERT TABLE 4 HERE}

\section{Nationality}

An interesting emergence which has occurred over the decades for both male and female athletes is the increase in the tendency to report on nationality. In athletics, for example, the expressions change from the athlete of a particular country e.g. Andrea Hughes of Australia (1994) to just nationality as an adjective. Recent trends also include identifying the athlete by just the phrase "the" followed by their nationality such as "so agitated was the Dane" (Daily Mail 1st July 2014) symbolically suggesting that their nationality is their key identity.

Nationalism in relation to gender has rarely been explored and in the analysis of Cathy Freeman's achievements during the Sydney 2000 Olympics gender lost its place as the primary framing device because of her importance as a symbol of national reconciliation (Wensing and Bruce, 2003). Harris and Clayton (2002) argue that the British print media frame male athletes as national heroes, contributing to 
the development of national identity and therefore demonstrating masculinity on a national scale. In 2014 the use of national identity as a describing feature of an athlete is prevalent amongst all sports and newspaper types such as:

first Scottish woman for two decades (Daily Telegraph $12^{\text {th }}$ July 2014) New Zealand teenager Lydia Ko also fired a final-round 65 to jump into a share of second place with US veteran Cristie Kerr (67) and American Angela Stanford (67) on 202 (Daily Telegraph $1^{\text {st }}$ July 2014) losing 6-3, 6-0 to the Russian in just 53 minutes (Daily Express $1^{\text {st }}$ July 2014)

Examples from other decades can be found in the following table (note the emergence of this trend for female athletes in 1994):

\section{INSERT TABLE 5 HERE}

By 2014 in tennis reporting there is an identifiable mantra of "name + age + nationality" which precedes many descriptions of play for both male and female athletes. The prominence of nationality in the framing of female athletes contrasts with the earlier work by Harris and Clayton (2002) in which they note that this strategy is mainly utilized for male athletes and is not used for females. This development in tennis reporting highlights that female athletes are now being framed in the previously masculine domain as national hero in sporting battle.

National identity through print reporting has also been attributed to developing a hierarchy of Britishness (Groves and Griggs, 2016) which was not evident in these results. In these reports there was often only a single or limited number of British athletes so the hierarchy of nationality was subtly played across nationalities. Groves and Griggs (2016) also note that the British print media have become more forgiving of the hybridity of dual identities amongst athletes in contrast to Poulton and Maguire (2012) 
who noted that the "plastic Brit" (non-native British national) narrative was prevalent in the lead up to London 2012 but demonstrated less so during the games. A 'pseudo plastic Brit' strategy was demonstrated through the narratives associated with Eugenie Bouchard as she approached the Wimbledon finals in 2014 with the press attempting to frame her Canadian heritage with Britishness on the basis of her mother's interest in the British Royal Family:

Genie Looks An Heir to The Throne (Daily Express 1st July 2014)

Princess by name, princess by nature (Daily Express 1st July 2014)

Bouchard is named after Princess Eugenie of York, so perhaps it was fitting she performed so well under the Centre Court roof in front of a Royal Box boasting the Duke of Kent and the Countess of Wessex (Daily Mail 1st July 2014)

Bouchard Shows Regal Touch as Cornett Crumbles (Daily Telegraph 1st July 2014)

Fearless princess Bouchard could soon become the new Queen of Wimbledon (The Guardian 1st July 2014)

The association of Bouchard with a pseudo British heritage allows the media to vicariously frame national identity where none exists.

\section{Relationships}

The framing of women athletes in terms of their relationships with others is a standard feature of reporting across the decades and there is little evidence of a change to this pattern. When relationships were highlighted with younger athletes this tended to be to parents such as:

"Eilish McColgan ... daughter of former world 10,000 metres champion Liz" (Daily Mail $11^{\text {th }}$ July 2014)

"Grace Davies-Redmond, the 16-year-old daughter of British Olympians Sharron Davies and Derek Redmond" (Daily Mail $9^{\text {th }}$ July 2014)

When, 18 months later, Sharp was finally given her gold medal -- presented by her father Cameron, a top-class Scottish sprinter from the Eighties (The Times July $10^{\text {th }}$ 2014)

“... but she has continued the family's sporting tradition. Her father finished 12th in 1991 and her grandfather, Freddie, won two world speedway crowns in the 
1950s" (The Times $11^{\text {th }}$ July 2014)

The reference to parents serves to highlight where there is a strong grounding in athletic heritage or alternatively the support that parents have given in developing opportunities. Whereas for older athletes relationships mentioned are often significant others such as "Serena Williams has suffered a love split from her coach Patrick Mouratoglou" (Daily Mirror $7^{\text {th }}$ July 2014) and "In that time she broke up with a long-term boyfriend and began dating Radek Stepanek" (The Times $4^{\text {th }}$ July 2014). The reporting of relationships occurred more in tennis because of the larger data set in that sport but the range of relationships reported extended to include siblings and friends for example: "She has fallen out big time with former 'best mate' Britain's Laura Robson" (Daily Express $5^{\text {th }}$ July 2014) and "The $13^{\text {th }}$ seed who has a twin sister called Beatrice and a brother called William" (Daily Mail $2^{\text {nd }}$ July 2014).

This trend emphasizes that athletic identity can be considered to be secondary to other identities, particularly those defined by relationships such as daughter, wife, girlfriend supporting the notion of media directing focus away from the athletic identity (Godoy-Pressland, 2013). This trend tessellates with the analysis of televised representation of female tennis players at Wimbledon where the mediated portrayal is still a gendered one in which athletes are shown as adolescent, owned by others and heterosexual (Kennedy, 2001). This aspect of framing the athletic identity as other (Harris and Clayton, 2002) by emphasizing the additional roles played by female competitors has remained consistent across the decades with Table 6 providing some illustrative examples from previous years:

\section{INSERT TABLE 6 HERE}

\section{Appearance}

The first shift away from appearance reporting towards performance occurred between 1984 and 1994 and it is pleasing to note that the emphasis on the reporting on the appearance of female athletes has diminished gradually over the decades and is still evident in the 2014 data set. There was a reversal in 
this trend in tennis (2004) when it had changed back towards an emphasis on appearance but was more of a feature of tennis reporting and not evident in athletics for that year. In UK legislation The Equality Act (2010) built on the previous Sex Discrimination Act (1975) and legislated that sex discrimination, along with eight other protected characteristics, is unlawful. Previously, the SDA (1975) had certain provisions through article 44 which allowed the discrimination of sexes in certain sporting contexts. The most overt form of sexist reporting which was common in the 1980 s is now much less frequent and very striking when it appears. For example:

Of course, it does not hurt that they are photogenic. Dressed in a dazzling aqua blue dress for a whirlwind day of publicity after winning the US Open last month, Michelle Wie showed she could hold her own in the fashion and beauty stakes alongside anyone on the tennis circuit (Mail on Sunday 6th July 2014).

Tennis remains the sport with the largest number of references to appearance which has associations with traditional notions of femininity (Harris and Clayton 2002; Pirinen, 1997) and continued reference to this allows the print media to maintain hegemonic discourses, for example: "The $5 \mathrm{ft}$ 10ins Montrealborn star has won legions of admirers with her supermodel looks, megawatt smile, blistering tennis and sense of humour" (Daily Express $4^{\text {th }}$ July 2014). Other sport examples include: "Morgan Lake is 5ft 10in with a movie-star name to match her prolific talent" (Daily Mail $9^{\text {th }}$ July 2014 - athletics) and "The 5ft 2in right-hander" (Daily Telegraph $11^{\text {th }}$ July 2014 - golf) demonstrating that the most common forms of appearance reporting across sports in 2014 are in relation to the height which potentially has a bearing on performance in some sports and is also a common feature in reporting for male athletes. The examples from previous decades demonstrate that commentary on appearance was traditionally very personal and served to emphasise attractive elements of appearance:

\section{INSERT TABLE 7 HERE}

\section{Discussion}


One of the emerging trends of the qualitative data from 2014 is a greater self-awareness from the print media with regards to male and female athletes. This emerges from a number of strategies such as: think pieces to identify the debate ('Our bodies are being used to lure people, say Spanish: Costume drama', Daily Telegraph 12th July 2014), the reporting of specific sporting examples which stem from structural differences (such as equal prize money and the development of the women's tennis event into five matches) and the reporting of specific individual examples (e.g. Suzi Wolff's Formula 1 race: "Susie is steadily making inroads in a sport that is more used to seeing scantily-clad pit girls than women behind the wheel. And yesterday's practice has put her within touching distance of her lifelong dream to compete in the world championship" Daily Mirror 5th July 2014). These examples demonstrate the media's engagement with the issues and an emerging maturity regarding their role. This contrasts, however, to the absence of reporting on women's soccer and the juxta positioning of this during the time period even starker. When quantitative results are included the disparity is even more startling (an increase of less than $1 \%$ of the total number of articles being categorized as female or both), despite the growth in number of sports pages. Such reporting supports the 'unevenness of social change' (Cooky et al., 2015: 263).

This data collection period in 2014 was within the Women's Super League season which started in April and concluded in October and was a significant season for the Super League because the second division was added during this period. As part of this expansion David Bernstein, Chair of the Football Association noted: "women's football is the area for potential of growth in the nation's favorite game" (cited in Football Association, 2013: 7). During the data collection period only two articles made reference to women's soccer: one reporting the semi-finals of the Super League Continental Cup (Sunday Mirror $13^{\text {th }}$ July 2014) and the other was about taking penalties (Independent $11^{\text {th }}$ July 2014). This serves to illustrate Jones et al.,'s (1999) position that women in non-gender appropriate sports are not reported to the same extent. The absence of women's soccer can be further compared to the 
increase in reporting of men's soccer which blossoms from $0.9 \%$ in 1984 to $19.2 \%$ in 2014 during a time period which saw the development of the British Premier League. The soccer seesaw of reporting during this time period is a significant strategy employed by the media to continue to frame the female athlete as "other". The female athlete also appears to be only reportable when they are winners. The increase in text and photo coverage occurs during major sporting events such as The Olympics (2.9\% of total coverage of female athletes in 2004 vs. $1.1 \%$ in 1994 and $2.2 \%$ in 2014) even though Redman et al., (2010) noted that this was still less than male coverage. Here female athletes are worthy of reporting because they are winners and these major sporting events conjure feelings of nationalism in audiences (Cooky, et al., 2015; Fink, 2015; Godoy-Pressland, 2013) thus enhancing further reporting of successful female athletes.

Inclusion of data from 2014 newspapers has highlighted some interesting and distinct areas for discourse. While the actual number of sports pages has continued to grow (5.8 in 1984 to 19.30 in 2014) the format of these pages has changed considerably. Sports media reporting is a growth area but women athletes are not benefitting from this growth. These changes serve to illustrate that proportional representation of female athletes is not making the same progress as seen in other spheres of social life (female athlete coverage decreased from $13 \%$ to $6.2 \%$; male athlete coverage increased from $80 \%$ to $89.9 \%$ ). The arguments put forward by Boyle and Haynes (2000) and Vincent (2004) that sports pages sell newspapers because they are read by males is supported by the latest data collection, especially with the increase in coverage of soccer during this period. The dominance of male sports journalists enables reporting to maintain a masculine slant while still paying lip service to social changes which have occurred elsewhere. Such an approach confirms the conclusion made by Pedersen et al., (2003) that emphasizing masculinity affirms male power and control and, thus, cultural norms persist. Poniatowski and Hardin (2012: 624) go as far as stating 'male athletes [make] the perfect sports heroes, 
because they are viewed as using muscular strength to succeed.' The ability of sports pages to remain 'gossip sheets' for men (Wenner, 1989) is therefore secured.

An additional change has been type of coverage. While the number of photographs has increased for both males $(23 \%-61.8 \%)$ and females $(39.5 \%-60.8 \%)$ the proportion of text articles has decreased for both males $(77 \%-38.2 \%)$ and females $(60.5 \%-39.2 \%)$. Newspapers may be using the visual image of female athletes to show an acknowledgement of social changes without having to overtly accept them (Kane and Greendorfer, 1994) but are more likely to be displaying a more image based form of reporting which has emerged from digital consumption of news. Newspapers may also be using increased photographic images of female athletes in order to provide conventional gender norms but this coverage, while showing a 'decline in overt sexism, is not synonymous with respectful coverage.' (Cooky et al., 2015: 281).

Interestingly, nationality as a focus in the print media appears to have increased over the past four decades as identity politics have become more prominent in the process of globalization. Crossman et al., (2007) in their examination of 2004 Wimbledon Championships, noted that nationality, as well as gender and competitiveness, was an important factor in determining the amount of coverage received. Often it is not the athlete but the journalist who creates nationality or race as a central focus of the story (Eagleman, 2013). Godoy-Pressland (2013) feels that by using nationality first, newspapers frame athletes as an homogenous group with a national identity. As noted previously in cases where the British print media are unable to explore the success of a British athlete they have undertaken the strategy of the "pseudo plastic Brit" in the example of Eugene Bouchard whereby they over associate with her links to Britain in order to hype up pseudo-nationality. The narrative created around nationality offers an opportunity for these athletes to become a source of great national pride, potentially increasing the vicarious nature of their accomplishments for readers (Vincent and Crossman, 2007). 
The idea that narrative for male and female athletes is now more similar with a greater emphasis on performance of female athletes also supports the same notion of masculinity and being a 'tom boy' decreases the threat to male dominance in sport (Godoy-Pressland, 2013). Previous research (e.g Groves and Griggs, 2016) has emphasized the links between the portrayal in the British print sports media and a British military past which links to this study. The increase in use of power/war related metaphors to describe female athletes' performance subscribes to this notion. However, GodoyPressland (2013) points out that such an approach also contains hidden sexism - success in sport is dependent on achieving a male standard. This highlights inequality because of asymmetrical gender marking. Newsprint use of power/war related metaphors, as illustrated in this research, may come at a cost with such gendered language promoting male supremacy and female subordination. Is this the reason why newspapers predominantly remain the property of male readers and why there has been less progress in providing a better proportional representation of female athletes? Cooky et al., (2015) provide a partial answer to these questions, and their comments support the outcomes of this longitudinal study. The sports media is an area of uneven social change in gender relations. Some female sports receive more coverage now than they have in the past (e.g. golf, motorsport, tennis), but the messages that are sent suggest that 'women's sport is less important, less exciting, and, therefore, less valued than men's sports.' (Cooky et al., 2015: 263).

\section{Conclusion and Future Directions}

It appears, after four decades of data collection, that the times, 'they are a changing' (Bernstein, 2002), but not enough and future research needs to continue to monitor this area for improvements. The constant comparison method employed by journalists to frame a hierarchy of athletes continues to frame women athletes against male athletes but in different ways to the 1980s. Bruce (2014) acknowledges that despite 30 years of activism within sports media there has been little change in quantity and quality of coverage and this paper clearly demonstrates the former but also outlines some 
of the changes in the latter. Future research could explore in greater depth the quality of reporting and include the words utilized to demonstrate equal levels of enthusiasm and excitement as that employed for men's reporting. She further challenges us to consider the unconscious process through which the media construct media sport as male and the female athlete as "the other" and to create a future where athletes are not automatically polarized into a binary division. Readership in British newsprint is currently estimated at $66 \%$ of all adults reading a print newspaper and, with the split between male and female readers estimated at 51:49\% (Newsworks, 2016), it is still important to review the trends of newsprint reporting. In addition to examining these trends, location of articles and photographs, as well as type of sport could be included so that not only is more coverage explored but also the range of men's sports is widened from the traditional summer sports. Future research could thus assist newsprint media in retaining its current position and readership. Little exploration on British print media has examined the styles in reporting between broadsheet and tabloid newspapers and this would be an important area for future direction. It is important, however with the digital age that future research also needs to embrace digital media in order to ascertain if such a platform can provide more equitable coverage.

\section{References}

Bernstein A (2002) Is it time for a victory lap? Changes in the media coverage of women in sport. International Review for the Sociology of Sport 37(3-4): 415-428

Biscomb K and Griggs G (2013) 'A splendid effort!' Print media reporting of England's women's performance in the 2009 Cricket World Cup. International Review for the Sociology of Sport 48(1): 99112

Biscomb K, Flatten K and Matheson H (1998) Read the papers, play the sport: A decade of gender change. In The Production and Consumption of Sports Culture. Merkel U, Lines G and McDonald I (eds) Brighton: LSA

Boyle R and Haynes R (2000) Power play: Sport, media and popular culture. London: Longman

Bruce T (2014) Assessing the sociology of sport: On media and representations of sports women. International Review for the Sociology of Sport 50(4-5): 380-384 
Caine B (1997) English Feminism 1870-1980. Oxford: Oxford University Press

Cooky C, Messner MA and Musto M 2015. 'It's Dude Time!': A Quarter Century of Excluding Women's Sports in Television and Highlight Shows. Communication and Sport, 3(3): 261-287

Crossman J, Vincent J and Speed H (2007) 'The times they are a-changing'. Gender comparisons in three national newspapers of the 2004 Wimbledon Championships. International Review for the Sociology of Sport 42(1): 27-41

Eagleman AN (2013) Constructing gender differences: newspaper portrayals of male and female gymnasts at the 2012 Olympic Games. Sport in Society: Cultures, Commerce, Media, Politics 18(2): 234247

Fink JS (2015) Female Athletes, Women's Sport, and the Sports Media Commercial Complex: Have We Really 'Come a Long Way, Baby'? Sport Management Review, 18: 331-342

Football Association (2013) The FA Women's Super League 2014-2018. London: Football Association George C, Hartley A and Paris J (2001) The representation of female athletes in textual and visual media. Corporate Communications: An International Journal 6(2): 94-101

Godoy-Pressland A (2013) The weekend as a male entity: how Sunday newspaper sports reporting centres around male activities, interests and language (2008 and 2009). Leisure Studies 32(2): 148-163

Groves M and Griggs G (2016) Riding in the shadows: The reaction of the British print media to Chris Froome's victory in the 2013 Tour de France. International Review for the Sociology of Sport 51(4): 428445

Harris J and Clayton B (2002) Femininity, masculinity, physicality and the English tabloid press. The case of Anna Kournikova. International Review for the Sociology of Sport 37(3-4): 397-413

Jones R, Murrell AJ and Jackson J et al (1999) Pretty versus powerful in the sports pages: print media coverage of U.S. women's Olympic gold medal winning teams. Journal of Sport and Social Issues 23(2): 183-192

Kane M J and Greendorfer SL (1994) The media's role in accommodating and resisting stereotyped images of women in sport. In Creedon P J (Ed.) (1994) Women, media and sport: Challenging gender values. London: Sage

Kennedy E (2001) She Wants to be a Sledgehammer? Tennis Femininities on British Television. Sport and Social Issues 25(1): 56-72

Le Masurier M (2016) Popular feminism and the second wave. Women's liberation, sexual liberation and Cleo Magazine. In Ritchie R, Hawkins S, Phillips N and Kleinberg SJ (eds) (2016) Women in magazines. Research, representation, production and consumption. London: Routledge pp 201-213 
Matheson H, Biscomb K and Shepherd M (2006a) It's not cricket! The changing representation of sport in UK newspapers. Paper delivered at the $1^{\text {st }}$ International Sporting Cultures Conference. $16^{\text {th }}-17^{\text {th }}$ May Liverpool

Matheson H, Biscomb K and Shepherd M (2006b) It's bloody football again. Paper delivered at the BASES 2006 Annual Conference. $11^{\text {th }}-13^{\text {th }}$ September, Walsall

Matheson H, Flatten K and Shepherd M (2005) Social and cultural impact of media representation of female athletes: A 20 year perspective. (Unpublished)

Media Info (2017) Daily Express Readership Figures. Available at <https://media.info> (accessed: 4 May 2017)

Newsworks (2016) Facts and figures (online) Available at <www.newsworks.org.uk> (accessed: 9 September 2016)

Northern and Shell (2013) Media Pack. Available at <http://images.express.co.uk/pdfs/ExpressFactbook.pdf> (accessed: 4 May 2017)

Nunnaly J (1978) Psychometric theory. New York: McGraw-Hill.

Pedersen PM (2002) Examining equality in newspaper photographs: a content analysis of the print media photographic coverage of interscholastic athletics. International Review for the Sociology of Sport 37(3-4): 303-318

Pedersen PM, Whisenant WA and Schneider RG (2003) Using a content analysis to examine the gendering of sports newspaper personnel and their coverage. Journal of Sport Management 17: 376-393

Pirinen R (1997) 'Catching up with the men: Finnish newspaper coverage of women's entry into traditionally male sports. International Review for the Sociology of Sport 32: 239-249

Poniatowski K and Hardin M (2012) 'The More Things Change, the More They . . ': Commentary During Women's Ice Hockey at the 2010 Olympic Games. Mass Communication and Society, 15: 622-674

Poulton E and Maguire J (2012) 'Plastic or fantastic Brits? Identity politics and English media representations of 'Team GB' during London 2012. JOMEC Journal. 1(2): 1-30

Ritchie R, Hawkins S, Phillips N and Kleinberg SJ (2016) Women in magazines. Research, representation, production and consumption. London: Routledge

Redman K, Webb L, Liao J and Markula P (2010) The United Kingdom. In Sportswomen at the Olympics. A global content analysis of newspaper coverage. Rotterdam: Sense

Sherry E, Osborne A and Nicholson M (2015) Images of sports women: a review. Sex Roles 74(7-8): 299309

Vincent J, Imwold C, Masemann V and Johnson JT (2002) A comparison of selected 'serious' and 'popular' British, Canadian, and United States newspaper coverage of female and male athletes 
competing in the Centennial Olympic Games: did female athletes receive equitable coverage in the 'Games of the Women'? International Review for the Sociology of Sport: 37(3/4): 319-335

Vincent J (2004) Game, set and match: The construction of gender in British newspaper coverage of the 2000 Wimbledon Championships. Sociology of Sport Journal, 21(4): 435-456

Vincent J and Crossman J (2007) Champions, a celebrity crossover and capitulator: the construction of gender in broadsheet newspapers' narratives about selected competitors at Wimbledon. International Journal of Sport Communication 1: 78-102

Wackwitz LA (1996) Sex testing in international women's athletics. Women in Sport and Physical Activity Journal 5(1): 51-68

Wenner L (ed) (1989) Media, sports and society. Thousand Oaks, CA: Sage

Wensing E and Bruce T (2003) Bending the Rules Media Representations of Gender During an International Sporting Event. International Review for the Sociology of Sport 38(4): 387-396

Whisenant WA and Pedersen PM (2004) Analyzing Attitudes Regarding Quantity and Quality of Sports Page Coverage: Athletic Director Perceptions of Newspaper Coverage Given to Interscholastic Sports. International Sports Journal Winter: 54-64 
Table 1 Demographic Data on Selected Newspapers

\begin{tabular}{|c|c|c|c|c|}
\hline & $\begin{array}{l}\text { Parent } \\
\text { Company/Owner }\end{array}$ & $\begin{array}{l}\text { Circulation Figures } \\
\text { (Dec 2016) }\end{array}$ & Readership & Readership - Age \\
\hline \multicolumn{5}{|c|}{ Broadsheets } \\
\hline $\begin{array}{l}\text { The Guardian } \\
\text { The Observer }\end{array}$ & $\begin{array}{l}\text { Guardian News and } \\
\text { Media } \\
\text { Scott Trust Limited }\end{array}$ & $\begin{array}{l}157,778 \\
193,593\end{array}$ & $864,000,000$ & $\begin{array}{l}15-24(16.5 \%) \\
25-34(11.7 \%) \\
35-44(15.7 \%) \\
45-54(16.8 \%) \\
55-64(18.0 \%) \\
65+(21.3 \%)\end{array}$ \\
\hline $\begin{array}{l}\text { Daily } \\
\text { Telegraph } \\
\text { Sunday } \\
\text { Telegraph }\end{array}$ & $\begin{array}{l}\text { Telegraph Media } \\
\text { Group } \\
\text { David and Frederick } \\
\text { Barclay }\end{array}$ & $\begin{array}{l}456,999 \\
378,603\end{array}$ & $1,183,000,000$ & $\begin{array}{l}15-24(5.0 \%) \\
25-34(5.5 \%) \\
35-44(6.3 \%) \\
45-54(8.9 \%) \\
55-64(15.9 \%) \\
65+(58.4 \%)\end{array}$ \\
\hline $\begin{array}{l}\text { Independent } \\
\text { Independent } \\
\text { on Sunday }\end{array}$ & $\begin{array}{l}\text { ESI Media } \\
\text { Evgeny Lebedev }\end{array}$ & $28,000-56,000^{1}$ & $\mathrm{~N} / \mathrm{A}$ & $\begin{array}{l}15-24(14.4 \%) \\
25-34(11.3 \%) \\
35-44(15.1 \%) \\
45-54(23.2 \%) \\
55-64(17.3 \%) \\
65+(18.7 \%)\end{array}$ \\
\hline \multicolumn{5}{|c|}{ Tabloids } \\
\hline $\begin{array}{l}\text { Daily Mail } \\
\text { Mail on } \\
\text { Sunday }\end{array}$ & $\begin{array}{l}\text { DMG Media } \\
\text { Viscount Rothmere }\end{array}$ & $\begin{array}{l}1,510,824 \\
1,355,760\end{array}$ & $3,355,000,000$ & $\begin{array}{l}15-24(6.8 \%) \\
25-34(5.8 \%) \\
35-44(6.4 \%) \\
45-54(12.5 \%) \\
55-64(18.0 \%) \\
65+(50.5 \%)\end{array}$ \\
\hline $\begin{array}{l}\text { Daily Mirror } \\
\text { Sunday Mirror }\end{array}$ & Trinity Mirror & $\begin{array}{l}756,142 \\
694,597\end{array}$ & $1,818,000,000$ & $\begin{array}{l}15-24(7.8 \%) \\
25-34(10.6 \%) \\
35-44(7.1 \%) \\
45-54(15.1 \%) \\
55-64(17.9 \%) \\
65+(41.4 \%)\end{array}$ \\
\hline $\begin{array}{l}\text { Daily Express } \\
\text { Sunday }\end{array}$ & $\begin{array}{l}\text { Northern and Shell } \\
\text { PLC }\end{array}$ & $\begin{array}{l}395,664^{2} \\
345,111\end{array}$ & $1,079,000,000^{3}$ & $\begin{array}{l}15-24(6 \%) \\
25-34(8 \%) \\
35-44(7 \%) \\
45-54(15 \%)\end{array}$ \\
\hline
\end{tabular}

${ }^{1}$ Different results reported by the BBC and the Daily Telegraph

${ }^{2}$ Source for most of the readership figures and data is Newsworks which present data from the Audit Bureau of Circulation. At the time of writing circulation figures for the print version of the Independent and the Independent on Sunday were not available because the print version of the newspaper ceased in March 2016.

http://www.newsworks.org.uk . Alternative source for Daily Express is Media Info https://media.info

${ }^{3}$ Source: Northern and Shell Media Pack http://images.express.co.uk/pdfs/ExpressFactbook.pdf 


\begin{tabular}{|l|l|l|l|l|}
\hline Express & & & & $55-64(64 \%)$ \\
\end{tabular}


Table 2 Growth in sports coverage/other coverage

\begin{tabular}{|c|c|c|c|}
\hline Year & & Sports Pages & Main pages \\
\hline 1984 & $\begin{array}{l}\text { Mean } \\
\mathrm{N} \\
\text { Std Dev }\end{array}$ & $\begin{array}{l}5.38 \\
2016 \\
1.66\end{array}$ & $\begin{array}{l}35.31 \\
1764 \\
8.11\end{array}$ \\
\hline 1994 & $\begin{array}{l}\text { Mean } \\
\mathrm{N} \\
\text { St Dev }\end{array}$ & $\begin{array}{l}9.89 \\
3419 \\
4.36\end{array}$ & $\begin{array}{l}50.27 \\
2850 \\
23.10\end{array}$ \\
\hline 2004 & $\begin{array}{l}\text { Mean } \\
\mathrm{N} \\
\text { St Dev }\end{array}$ & $\begin{array}{l}14.91 \\
5641 \\
5.96\end{array}$ & $\begin{array}{l}67.35 \\
3669 \\
31.14\end{array}$ \\
\hline 2014 & $\begin{array}{l}\text { Mean } \\
\mathrm{N} \\
\text { St Dev }\end{array}$ & $\begin{array}{l}19.30 \\
6181 \\
6.48\end{array}$ & $\begin{array}{l}62.31 \\
5960 \\
20.62\end{array}$ \\
\hline Totals & $\begin{array}{l}\text { Mean } \\
\mathrm{N} \\
\text { St Dev }\end{array}$ & $\begin{array}{l}14.37 \\
17257 \\
7.28\end{array}$ & $\begin{array}{l}57.86 \\
14243 \\
25.47\end{array}$ \\
\hline
\end{tabular}


Figure 1 Percent of total sports coverage by gender across decades

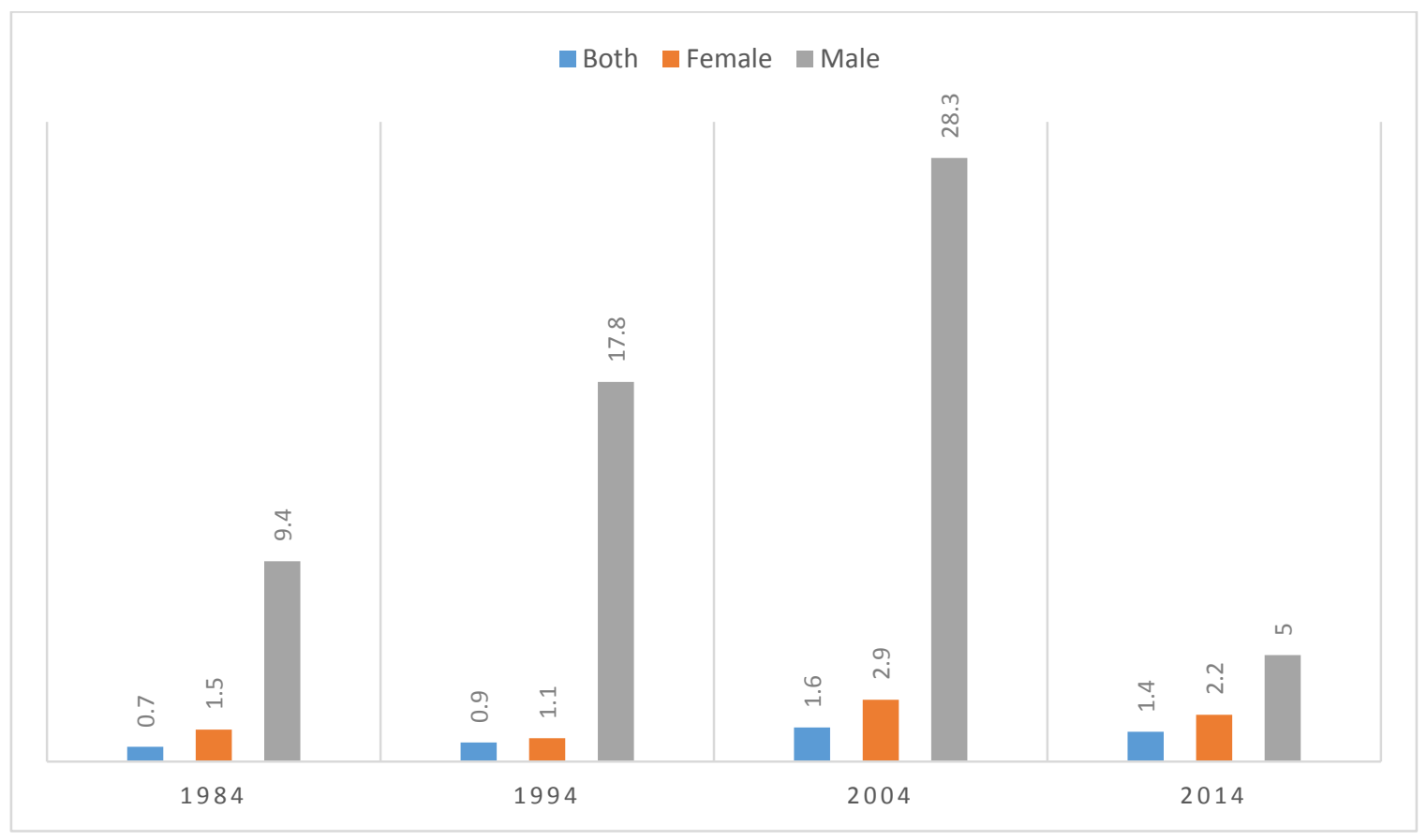


Figure 2 Percent Changes in Photo and Text for All Newspapers

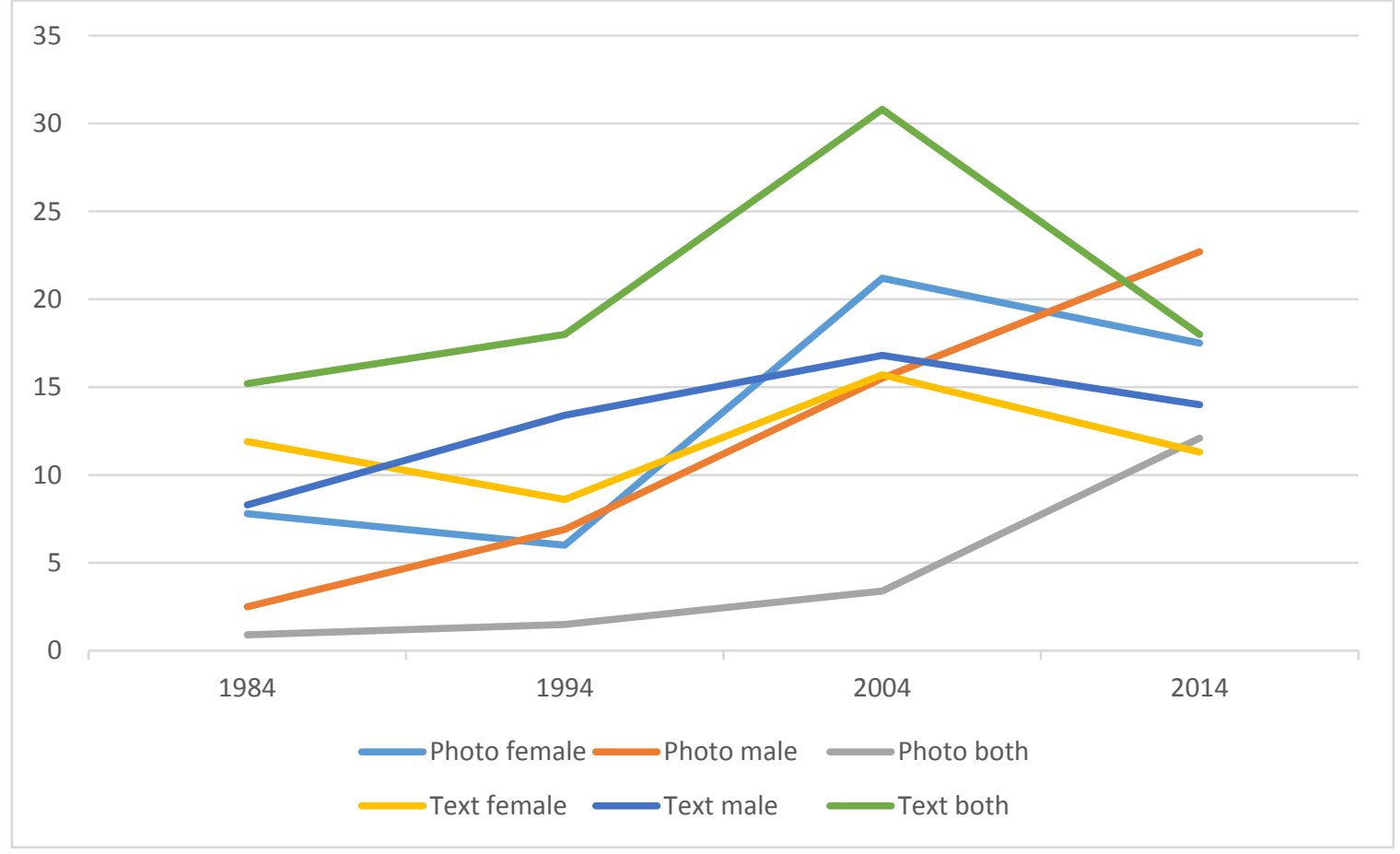


Figure 3a Percent of total sports coverage 1984

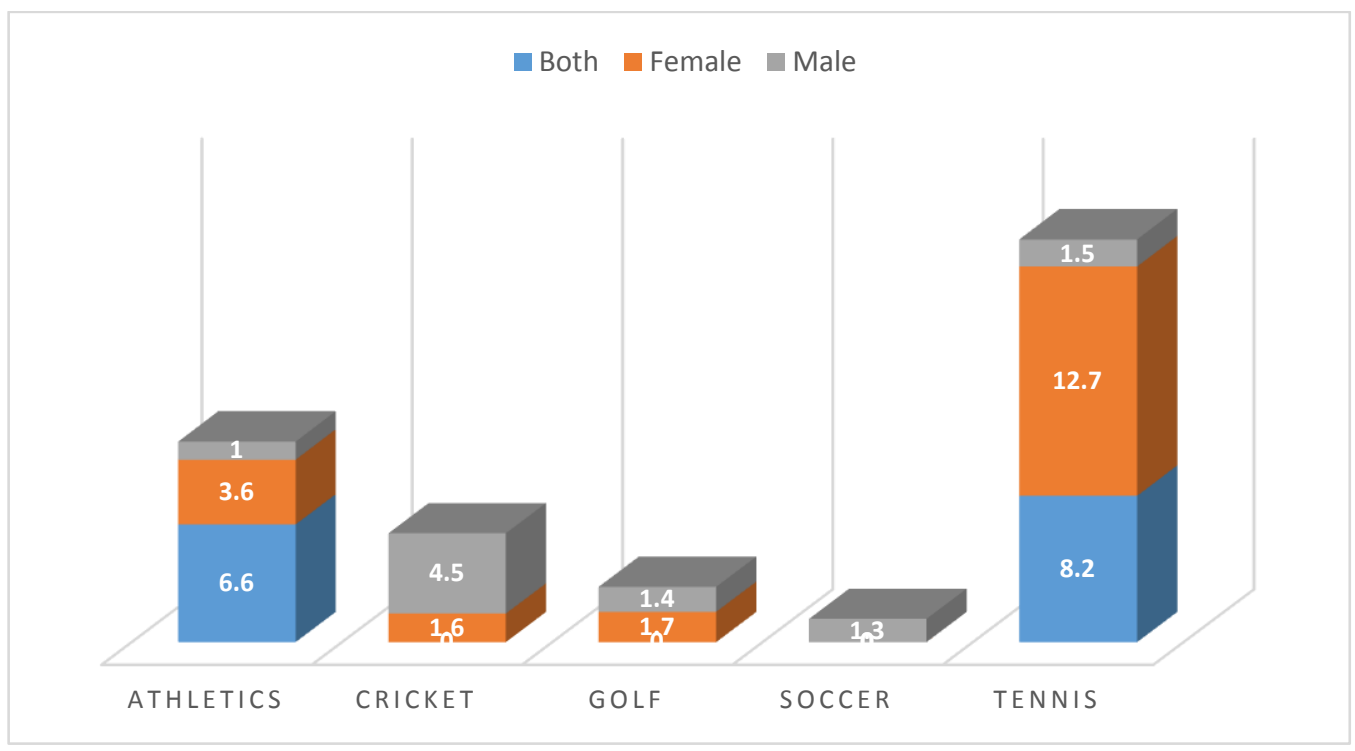


Figure 3b Percent of total sports coverage 1994

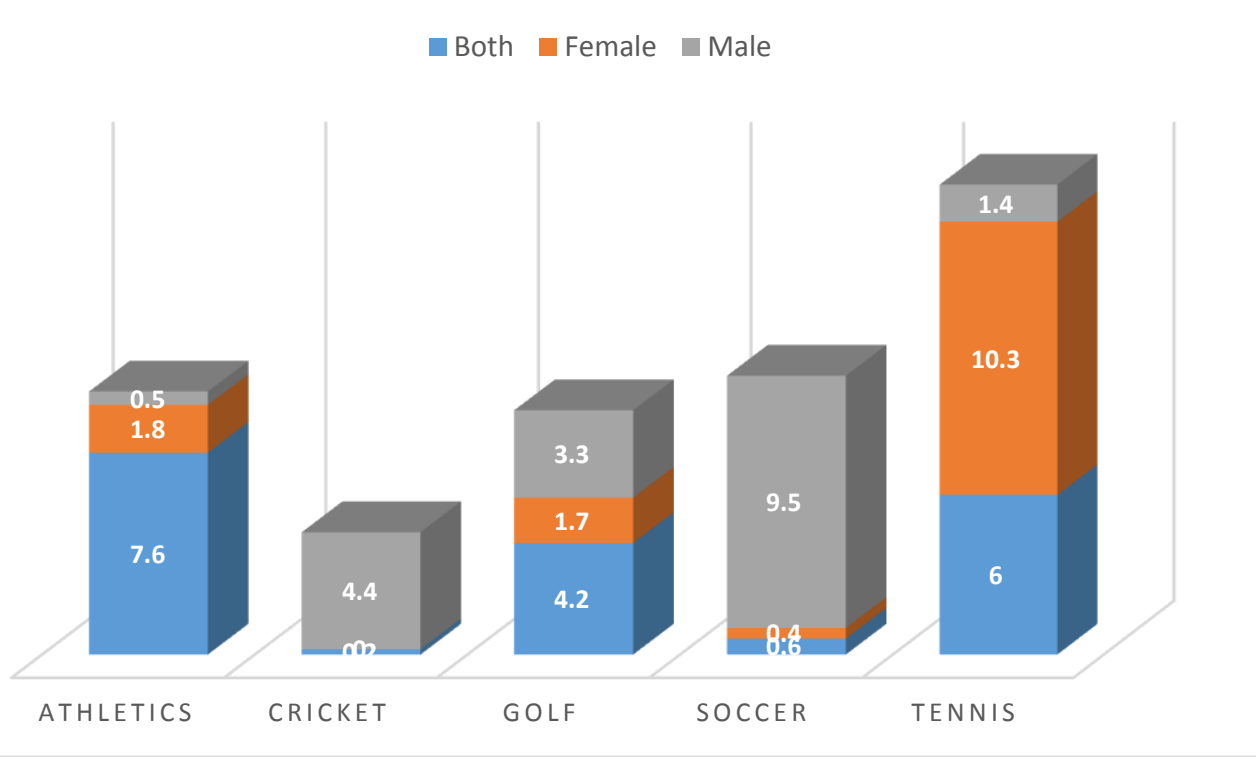


Figure 3d Percent total sports coverage 2014

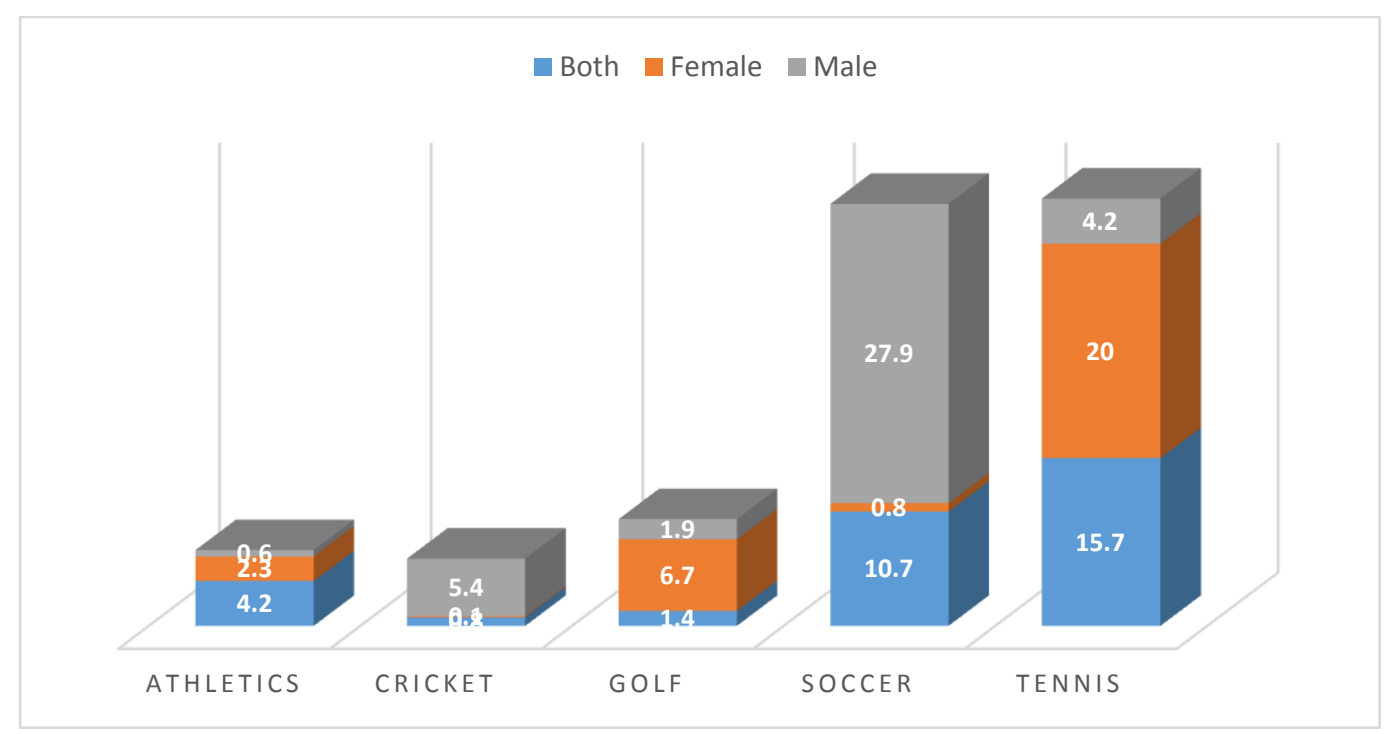


Figure 3c Percent of total sports coverage 2004

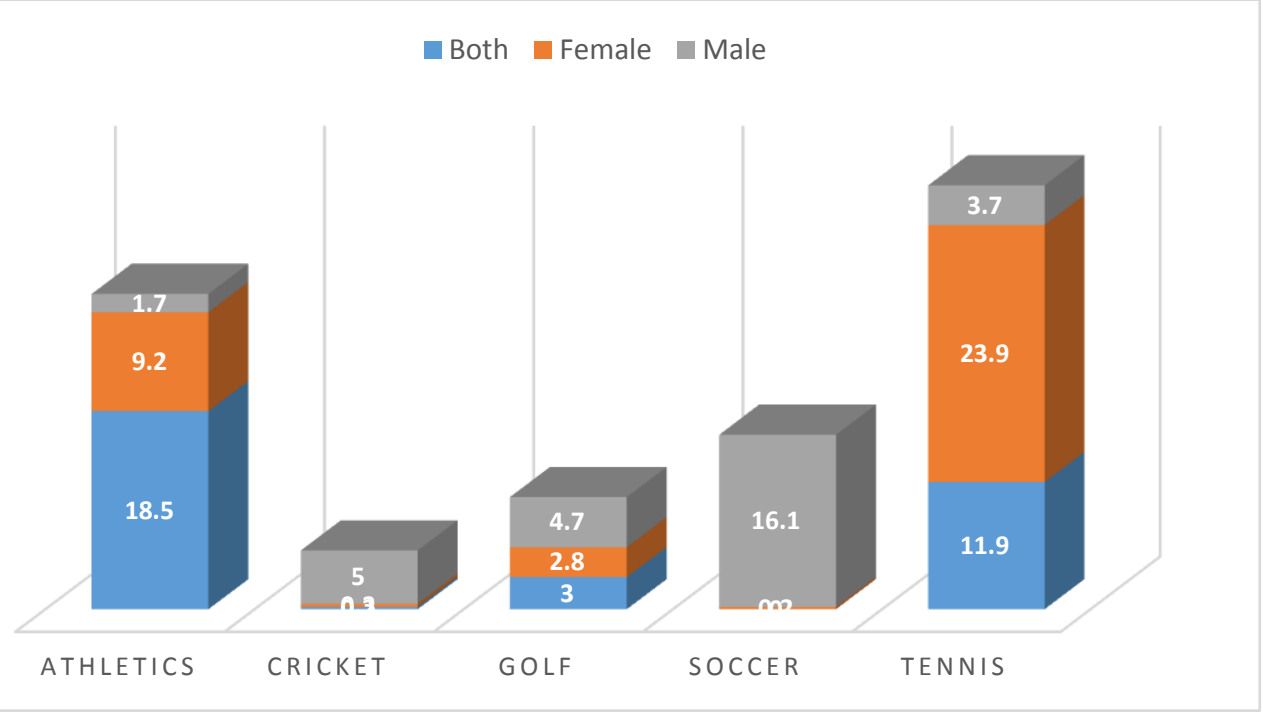

Figure 4: Selective Sports Timeline: 1984 - 2014 
1984

First

data

set

Wimbledon -

McEnroe v Connors

Navratilova v Evert

\section{Cricket -}

England v West Indies (0-5)

England Women v NZ Women (3 drawn)

Soccer -
Mexico

1986

1994
Second
data
set

Wimbledon -

Sampras v Ivanisevic

Martinez v Navratilova

\section{Cricket -}

England v S Africa (1-1)

England v NZ (1-0)
2004

Third

data

set

Wimbledon -

Federer v Roddick

Sharapova v S Williams

\section{Cricket -}

England v West Indies (4-0)

England v NZ (3-0)

France

1998

\section{Italia \\ 1990 \\ Premier \\ League}
Japan/Korea Greece Germany 2002
2006

\section{Barcelona}

Atlanta

Olympics

Olympics

\section{Olympics}

Olympics
Sydney

Olympics

\section{Athens}

Olympics
2014

Fourth

data

set

Commonwealth Games -

$$
\begin{aligned}
& \text { Canada } \\
& 1994
\end{aligned}
$$

\section{British Golf -}

Men's Open

\section{Wimbledon -}

Djokovic v Federer

Kvitova v Bouchard

\section{Cricket -}

England v NZ (3-1)

England Women - professional status

World Twenty20

$\begin{array}{cc}\text { S Africa } & \text { Brazil } \\ 2010 & 2014\end{array}$

Beijing London

Olympics Olympics 
Table 3: Examples of Performance Reporting 1984-2004

\begin{tabular}{|c|c|c|}
\hline 1984 & 1994 & 2004 \\
\hline $\begin{array}{l}\text { marvellously she ran the race } \\
\text { (Daily Mail 1984) } \\
\text { remarkable finishing pace (Daily } \\
\text { Mail 1984) } \\
\text { she possessed neither the } \\
\text { variety of strokes nor the } \\
\text { consistent depth (The Guardian } \\
5^{\text {th }} \text { July 1984) } \\
\text { fierce ground strokes (The Mail } \\
\text { on Sunday } 1^{\text {st } J u l y ~ 1984) ~}\end{array}$ & $\begin{array}{l}\text { that she is still very much at the } \\
\text { top of her event (The Guardian } \\
2^{\text {nd }} \text { July } 1994 \text { ) } \\
\text { surrendered feebly in the fourth } \\
\text { round (The Times } 1^{\text {st }} \text { July } 1994 \text { ) } \\
\text { hitting a bewildering array of } \\
\text { passing shots (The Guardian } 1^{\text {st }} \\
\text { July 1994) }\end{array}$ & $\begin{array}{l}\text { She clocked one minute } 58.71 \\
\text { seconds to see off a world class } \\
\text { field (Daily Express } 5^{\text {th }} \text { July } 2004 \text { ) } \\
\text { Her every thudding serve, } \\
\text { elegant groundstroke and neatly } \\
\text { placed volley appeared so } \\
\text { effortless for the first } 29 \text { minutes } \\
\text { (The Guardian } 1^{\text {st }} \text { July } 2004 \text { ) } \\
\text { Mauresmo is playing nowhere } \\
\text { near the level needed to trouble } \\
\text { the defending champion (The } \\
\text { Independent } 1^{\text {st }} \text { July } 2004 \text { ) }\end{array}$ \\
\hline
\end{tabular}


Table 4: Examples of Descriptive Performance Reporting 1984-2004

\begin{tabular}{|c|c|c|}
\hline 1984 & 1994 & 2004 \\
\hline $\begin{array}{l}\text { High priestess (The Guardian } 7^{\text {th }} \\
\text { July 1984) } \\
\text { Playing the role of chilling } \\
\text { executioner (Daily Telegraph } 6^{\text {th }} \\
\text { July 1984) }\end{array}$ & $\begin{array}{l}\text { played a crucial part in the race } \\
\text { (Daily Telegraph } 9^{\text {th }} \text { July 1994) } \\
\text { thumped down her spikes } \\
\text { almost arrogantly (The Guardian } \\
2^{\text {nd }} \text { July 1994) } \\
\text { bizarre twist to her troubled } \\
\text { career (The Guardian } 11^{\text {th }} \text { July } \\
\text { 1994) } \\
\text { second fiddle on the court (Daily } \\
\text { Telegraph } 4^{\text {th }} \text { July 1994) } \\
\text { cutting McNeil apart with her } \\
\text { accuracy and volleying skill (The } \\
\text { Guardian } 1^{\text {st }} \text { July 1994) }\end{array}$ & $\begin{array}{l}\text { registering a superb victory over } \\
\text { the distance (Daily Express } 5^{\text {th }} \\
\text { July 2004) } \\
\text { fine victory (The Independent } 4^{\text {th }} \\
\text { July 2004) } \\
\text { the superwoman of Sydney four } \\
\text { years ago (The Independent } 13^{\text {th }} \\
\text { July 2004) } \\
\text { the severity of this beating (Daily } \\
\text { Express } 1^{\text {st July 2004) }} \\
\text { battling on (The Independent } 2^{\text {nd }} \\
\text { July 2004) }\end{array}$ \\
\hline
\end{tabular}


Table 5: Reporting of Nationality 1994-2004

\begin{tabular}{|c|c|}
\hline 1994 & 2004 \\
\hline $\begin{array}{l}\text { Andrea Hughes, of Australia (The Independent } 9^{\text {th }} \\
\text { July 1994) }\end{array}$ & $\begin{array}{l}\text { Moroccan Hasna Benhassi (1:59.21) and Russia's } \\
\text { Natalya Tsyganaova (Daily Express } 5{ }^{\text {th }} \text { July 2004) }\end{array}$ \\
\hline $\begin{array}{l}\text { Maricica Puica, of Romania in } 1986 \text { (Daily } \\
\text { Telegraph } 9^{\text {th }} \text { July 1994) }\end{array}$ & $\begin{array}{l}\text { The 39-year-old German (Daily Mirror } 9^{\text {th }} \text { July } \\
\text { 2004) }\end{array}$ \\
\hline $\begin{array}{l}\text { kept the Spaniard at arm's length (Guardian } 1^{\text {st }} \\
\text { July 1994) }\end{array}$ & $\begin{array}{l}\text { the American hurling down big serves (The } \\
\text { Guardian } 1^{\text {st }} \text { July 2004) }\end{array}$ \\
\hline $\begin{array}{l}\text { lived her tennis life in the shadow of another } \\
\text { Spaniard (Daily Telegraph } 4^{\text {th }} \text { July 1994) }\end{array}$ & $\begin{array}{l}\text { The Frenchwoman recovered her poise (The } \\
\text { Guardian } 1^{\text {st }} \text { July 2004) }\end{array}$ \\
\hline
\end{tabular}


Table 6: Examples of Relationship Reporting 1984-2004

\begin{tabular}{|c|c|c|}
\hline 1984 & 1994 & 2004 \\
\hline $\begin{array}{l}\text { Athletic separation from her } \\
\text { husband (Daily Mail } 5^{\text {th }} \text { July } \\
\text { 1984) } \\
\text { Mother of six (Daily Telegraph } \\
5^{\text {th }} \text { July 1984) }\end{array}$ & $\begin{array}{l}\text { [Zola Pietersen], formerly Zola } \\
\text { Budd (The Times } 11^{\text {th }} \text { July 1994) } \\
\text { The proud parents were able to } \\
\text { join in the weekend celebrations } \\
\text { (The Independent } 3^{\text {rd }} \text { July } 1994 \text { ) }\end{array}$ & $\begin{array}{l}\text { Montgomery's girlfriend Marion } \\
\text { Jones (Daily Mirror } 9^{\text {th }} \text { July 2004) } \\
\text { By contrast her partner (The } \\
\text { Guardian } 10^{\text {th }} \text { July 2004) } \\
\text { She is Michaela Krajicek, half } \\
\text { sister of Richard, the Wimbledon } \\
\text { men's champion in } 1996 \text { (Daily } \\
\text { Express } 2^{\text {nd }} \text { July 2004) } \\
\text { pictured with her dad (Sunday } \\
\text { Mirror } 4{ }^{\text {th }} \text { July 2004) }\end{array}$ \\
\hline
\end{tabular}


Table 7: Examples of Appearance Reporting 1984-2004

\begin{tabular}{|c|c|c|}
\hline 1984 & 1994 & 2004 \\
\hline $\begin{array}{l}\text { Glamorous (Daily Mail } 10^{\text {th }} \text { July } \\
1984 \\
\text { Striking } 5 f t 11 \text { in (Daily Mail } 10^{\text {th }} \\
\text { July 1984) } \\
\text { barefoot slim legs (Daily Mail } \\
14^{\text {th } J u l y ~ 1984) ~} \\
\text { Pertly attractive (Daily Telegraph } \\
1^{\text {st } J u l y ~ 1984) ~} \\
\text { baby doll blonde (The Guardian } \\
2^{\text {nd July } 1984)} \\
\text { (Daily look of a fourth former } \\
\text { (Dail } 3^{\text {rd }} \text { July 1984) }\end{array}$ & $\begin{array}{l}\text { Looked anything but bovine (The } \\
\left.\text { Observer } 3^{\text {rd }} \text { July } 1994\right) \\
\text { Square cut muscular physique } \\
\text { (The Observer } 3^{\text {rd }} \text { July 1994) } \\
\text { Equally elegant (Daily Telegraph } \\
1^{\text {st } J u l y ~ 1994) ~}\end{array}$ & $\begin{array}{l}\text { Sharapova is a tennis player first, } \\
\text { and eye-candy a distant second } \\
\text { (Daily Express } 3^{\text {rd }} \text { July } 2004 \text { ) } \\
\text { long blonde hair and endless legs } \\
\left.\text { (Daily Mail } 2^{\text {nd }} \text { July } 2004\right) \\
\text { leggy blonde's tennis (Daily } \\
\text { Telegraph } 2^{\text {nd }} \text { July 2004) }\end{array}$ \\
\hline
\end{tabular}

